\title{
Reinforcing Europe's failed fiscal regulatory state
}

\author{
Scott Greer ${ }^{1}$ and Holly Jarman²,
}

Forthcoming, pp. 122-143 of Bruno Dallago, Gert Guri and John McGowan, eds. A Global Perspective on the European Economic Crisis. London: Routledge 2016.

\begin{abstract}
$^{3}$
Fiscal governance in the EU is an exemplary case of the regulatory state; the EU governs member states' fiscal and public policies through rules rather than expenditure. The weaknesses of the EU fiscal regulatory state were apparent to observers from before the introduction of the Euro, and were exposed in the financial crisis. EU leaders have nonetheless redoubled their commitment, expanding the range of policies subject to the fiscal regulatory stage, its intrusiveness into member state policies, and the penalties for noncompliance. We review and analyze them and conclude that there is a high risk that the EU fiscal governance will further increase the intrusiveness and unpopularity of the EU without disciplining member states or markets.
\end{abstract}

\section{Introduction}

Europe's monetary policymakers have saved the Euro. They protected the European monetary system. They have prevented obvious defaults on government debt and ended speculative attacks on individual countries. They have defended a currency union that has all the deflationary properties of the gold standard, which is a notable achievement in democratic states, and fought off the first real challenge to their decisions from a democratically elected member state government. They have done all this while advancing a certain kind of European integration, giving the EU a range of powers and responsibilities to oversee essentially the fiscal and public policies of its member states. They have, in other words, built a much more complex, legally entrenched, and powerful fiscal regulatory state for the EU.

The EU has long been a nearly ideal case of a "regulatory state," capable of regulating but not redistributing or even paying the costs associated with implementing its rules (Majone 1994; Schelkle 2009). This is because its core tool for public policy, whether labor law, environmental law, or competition law, is law. EU policy is mostly about the development, deployment, and centralized or decentralized enforcement ${ }^{4}$ of regulations on markets and on member states. Unlike most other governments, it has few of its own resources The Commission is a small and policy-focused organization) and its budget is a derisory one percent of the EU GDP, most of which goes to structural funds projects or agricultural policy and does not meaningfully compensate for the effects of the internal market or EU law (Pasimeni 2014). The costs of regulations are borne by the regulated, after all.

This European regulatory state has long had a fiscal side, with the EU deploying regulations to constrain member state fiscal policy, but it was weak- persistently violated, and rewritten in 2005 to suit Germany and France when they were in violation. The EU's response to its various debt crises has been to substantially expand the breadth, automaticity, and punitiveness of this regulation over member state finances, rather than add other policy tools, such as redistribution, that would stabilize its union. The ambition and integrative drive of the reforms is striking and underappreciated. The breadth and intimacy of fiscal surveillance and the mechanisms for punishing transgressions of the Stability and Growth Pact is a dramatic increase in the formal powers of the EU. It is intended to have significant, constraining, effects on domestic democratic politics ${ }^{5}$. The EU now has a competency over the detailed shape of every aspect of the welfare state, with member states' health, education, pension and other policies subject to EU review and censure in the name of fiscal stringency.

\footnotetext{
${ }^{1}$ Department of Health Management and Policy, University of Michigan School of Public Health and European Observatory on Health Systems and Policies, Brussels slgreer@,umich.edu

${ }^{2}$ Department of Health Management and Policy, University of Michigan School of Public Health hjarman@umich.edu

${ }^{3}$ We would like to thank Robert Fannion, Kate McNamara, and participants in the Chapel Hill conference in September 2014 for their excellent comments. This paper draws heavily on Greer et al 2014.

4 For which, see Kelemen 2011.

5 A number of authors have argued that this crisis response is not a step forward for the EU; unlike previous crises, it produced not enough or the wrong kind of integration (Boyer 2013; Lefkofridi and Schmitter 2014). It seems to us that a significant increase in EU power vis-à-vis member states, even if illadvised or supported by governments, fits most definitions of European integration.
} 
It is a big step for EU integration, but a step in the same direction as before- towards reinforcing its fiscal regulatory state. The next two sections discuss the contents of their choice in more detail. European integration did not have to be a product of the crisis, and neither did a redoubled commitment to a fiscal regulatory approach that puts all the burden of adjustment to the Euro on domestic budgets and workers. Europe's political leaders have opted for neither a breakup of its unstable currency zone nor the kind of redistribution that would take the burden of adjustment off of their populations. As of late summer 2015, the Greek government, despite strong support for its challenge to the Eurozone, caved in and accepted an agreement that keeps it in the Euro at a very high price. Even the left-wing government of Alex Tsipras, with a platform opposed to austerity, popular support ratifying its position, and an invitation from the German finance minister to a (wholly illegal) five year holiday from the currency, ${ }^{6}$ would not take the step to leave the Euro that is so strongly associated with austerity and economic crisis. Breakup was averted. Meanwhile, traditional sidepayments in the EU budget such as structural funds, or even the newer investment schemes, are clearly inadequate to cope with the disparities in the EU, while the substantial sums of money spent on rescuing government debt of the countries in receivership constitutes a transfer of public money from creditor states to the bondholders more than the citizens and is not supposed to continue. Instead, the new EU fiscal governance regime that they have designed extends and strengthens the EU's regulatory policies over fiscal policy while effectively requiring that signatories of its Fiscal Compact treaty constitutionalize restrictive EU budget rules.

We conclude that the success of this arrangement is unclear and frankly unlikely- as we would expect from the difficulties that the Eurozone fiscal regulatory state experienced before 2010. It is unlikely that the putatively credibility-enhancing powers of the fiscal governance system saved the Euro. As we argue below, there is a strong case that the European Central Bank, rather than a convincing preventative regime with credible commitments to austerity, has been maintaining the European monetary system. Nor is it clear that it will work on its own terms. Reformed EU fiscal governance builds in multiple, redundant, and much tougher mechanisms for monitoring and punishing member state decisions, reinforced by a treaty; incorporates an ambitious new European Semester in order to "reform" areas such as health and education long thought beyond the EU's competencies; and extends its decentralized enforcement provisions with domestic constitutional amendments. Nonetheless, the problems governments face, the effects of economic cycles, party politics and domestic politics could still create a coalition that could blunt its implementation, notably in the Council. ${ }^{7}$ Nor is it clear that it will produce broader benefits that justify such major changes. There is essentially no evidence that austerity on its own produces economic growth, and without economic growth it is very difficult to satisfy the expectations of bond markets or voters.

In short, we argue that the Eurozone fiscal governance system is a major increase in EU power, but one that perpetuates a regulatory approach to fiscal policy that has historically failed to address the problems of the Euro, and that while fiscal governance can constrain member states it is unlikely to be a credible constraint on overall fiscal policy. We make the argument in the following sections. First we discuss the crisis measures taken by the "troika" in peripheral Eurozone member states, where the EU became involved in extremely intimate domestic policymaking in areas such as health care and labor law. The subsequent section discusses the EU's formal, institutional response, which was a block of legislation, an intergovernmental treaty (with constitutional effects in its signatories), and a large new apparatus dedicated to making EU fiscal rules more effective by broadening them into more policy areas and increasing the force and automaticity of their punishments. This structure has significant effects on politics, with limited participation by member state legislatures, the European Parliament, or interests (civil society) relative to older EU politics- and use of the data from often derided soft law mechanisms to formulate arguments and targets.

There are a variety of political reasons why the EU might have preferred an expanded fiscal regulatory state over more obvious options such as breaking up the currency union or creating redistributive mechanisms to cushion the effects of speculation and economic change. It is clear, though, that fiscal governance did not stop the bond market crisis. As the fourth section explains, the ECB did that, while also taking on a set of unorthodox roles that neither treaties nor economic theory suggest it should. The EU's mostly right-wing governments are not alone worldwide in opting for austere fiscal policy for themselves and others but accepting more exotic monetary policy interventions by central banks to avoid deflation, albeit with disturbing distributional effects.

Our conclusion is that the Eurozone fiscal regulatory state will continue to malfunction. There is no clear reason to expect that it will succeed on its own terms (constraining member state fiscal and public policy), or produce growth or equity. The European Union faces a dangerous situation. It is equipped with big new

\footnotetext{
6 Paul Taylor, “Analysis: IMF Threat to pull out of Greek bailout challenges Germany”. Reuters July 15, 2015. http:/www.reuters.com/article/2015/07/15/us-eurozone-greece-imf-threat-analysis-idUSKCN0PP1IS20150715

7 The most extensive experiment with austerity rules, the United States, does not seem to support the idea that the rules enforce budgetary stability. Bond markets appear to do the enforcing by charging higher interest rates to what buyers see as weaker governments. (Kelemen and Teo 2012)
} 
claims of authority over member states and their policies, but at risk of those claims being rejected by states and their voters.

\section{Eurozone crisis measures: Conditional lending for structural adjustment}

Economic Adjustment Programmes, aka Memoranda of Understanding, are the conditions on the loans that the Troika of IMF, ECB and Commission (on behalf of the European Financial Stability Fund and the European Financial Stabilization Mechanism and, as of September 2012, the European Financial Stability Mechanism) oversee ${ }^{8}$. They emerged as the ad hoc responses to real or expected crises in the debt markets of peripheral states but, as subsequent sections below explain, have now been formalized (in the two-pack, below) as a response and deterrent to future crisis. The basic structure of conditional lending is simple: lenders set a number of requirements for policy change and fiscal targets, and "tranches" of the loan are contingent on fulfilling the policy requirements. EAP conditionality is tough, but it is worth noting that it comes with support far beyond what indebted countries in the rest of the world could receive: the two Greek bailouts so far total about $€ 190 \mathrm{bn}$, for a country with a GDP of just under $€ 300$ bn per year

The EAPs are intended to change the trajectories of countries in deep trouble, some of which had clear structural problems even before the boom that bust in 2008, and deter countries from behavior that might lead them to similar crises. They assume that moral hazard and bad public policy caused the crises of the Eurozone, and can be addressed with painful reforms (pain, to address the moral hazard; reforms, to address the lack of competitiveness; and painful reforms, to overcome domestic interests that otherwise would block change). Moral hazard, meanwhile, has apparently been redefined from its original meaning into something that applies to debtors rather than lenders. Deterring borrowing, rather than rash lending, is the new meaning of moral hazard and purpose of the policy.

This is not good economic history. Specific stories varied in both the causes of the crises and the specific origins of the EAPs. Ireland and Cyprus did not request their EAPs but were forced into them by other member states worried about financial contagion. Spain received a bailout but escaped an EAP in name and conditionality, probably because the Spanish government knew that a formal bailout for Spain would be too expensive and risky. Likewise, the underlying problems and proximate causes of their debt problems were also different. Only in Greece and possibly Cyprus was there a strong argument that distinctively bad government, rather than speculative private financial activities, was the main problem. Ireland and Spain had been compliant with Eurozone fiscal targets and enjoyed fiscally stronger positions than Germany in 2008. Their problem was that the good times were financed by speculative capital inflows, and that the chosen solution was the nationalization of bad banking debts rather than sharing losses with speculative investors. It is not at all clear why structural adjustment lending was the solution for them.

The operation and effects of structural adjustment conditional lending have been much discussed in a large international literature reviewed by Greer (2014a) and summarized in the rest of this section (also Rodrik 2006). The form is of a conditional loan, and the content is "structural adjustment," which means liberalization (e.g. deregulation of markets, including labor protection), privatization (of state owned enterprises), reduction in state expenditure (e.g. through reduced pay and conditions for civil servants) and, in the EU cases, some increased taxes and improved tax collection.

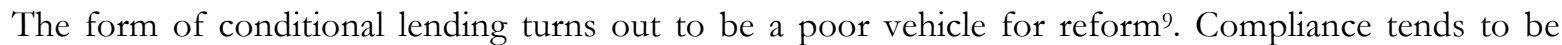
poor. In general, compliance with ultimata without a sense of ownership tends to be poor. Sructural adjustment lending is just that- an ultimatum. Proliferating complex demands for policy change, meanwhile, creates more opportunities for noncompliance. It is often hoped that structural adjustment will displace corrupt elites and practices, but they frequently manage to pass on the cost of the cuts to more vulnerable populations. It is not hard to see how budget cuts in health or education might lead to reduced access rather than reduced corruption. These problems produce a running debate: do structural adjustment policies produce poor outcomes, or does poor compliance with the good ideas explain the repeated failures of states to escape poverty through accepting conditional structural adjustment loans (Vreeland 2007)?

The content of structural adjustment reforms is focused on budgetary constraint, labor market liberalization, privatization, and deregulation. In the EAPs, it means policies including liberalization of markets in areas such as energy, transportation, and services; reductions in salaries and benefits for public employees; privatization of some state owned firms; changes in labor law to make hiring and firing easier; and a few targeted investments such as health IT. In content, the record is also poor. This package, found in the EAPs as well as

8 For the EAPs see the “Occasional papers" site of DG ECFIN http://ec.europa.eu/economy_finance/publications/occasional_paper/index_en.htm or the country pages on the IMF website.

9 See Greer (2014a) for the literature review underpinning this and the next paragraph. 
most other structural adjustment programs, has mostly negative effects on society and social investment that are not reliably balanced by economic improvements (Huber and Stephens 2012). It does not produce economic growth on average (Easterly 2005), and the dispersion in economic growth among countries exiting structural adjustment is large (so if we remove successful outliers like developmental South Korea, whose success is hardly due to obeying the IMF, its record becomes worse). Nor does it produce social gains, and it costs those who cannot delay activities such as ill health, intrauterine development, labor market entry, or primary education until better economic times (Peabody 1996). It usually seems to increase income inequality. It also produces complex unexpected outcomes when structural adjustment plans are put into practice, as a vast literature cataloguing policy failures attests ${ }^{10}$.

The record of the EAPs in Europe is, as the structural adjustment literature would predict, poor. Compliance with specific policies must be inferred from the periodic EAP reports; what it suggests is that Greece was strikingly noncompliant and Ireland especially compliant. As of mid-2015 Ireland and Portugal have exited their full-scale EAPs, as has Spain its partial EAP. As of the end of 2014, according to Eurostat, the debt:GDP ratio of the four Eurozone countries was between 177.1\% in Greece, and 107.5\% in Ireland. For comparison, the equivalent numbers are $74.7 \%$ for Germany, 95\% for France, $91.9 \%$ for the Eurozone overall, and a low of $10.6 \%$ for Estonia. The ex-Troika countries are all still vulnerable to speculative attack, and are like most of the EU nowhere near the shared target of a $60 \%$ debt:GDP ratio. Most economic indicators remain worrisome, notably unemployment. In December 2014, Eurostat's reported unemployment rates were: Greece, $25.8 \%$, Cyprus, $16.4 \%$, Portugal $13.4 \%$, and Ireland 10.5\%, which is concentrated among the youth. Such unemployment is by this point probably structural and difficult or impossible to reverse without rapid economic growth and effective, expensive, active labor market policies.

The EAPs were chronologically the first major part of post-2008 Eurozone fiscal governance, and have been entrenched in subsequent law as the EU's emergency response to future sovereign debt crises. They were an intrusive and expensive policy intervention better known in developing countries than in Europe, but their policy prescriptions have been quite conventional for decades, and it is unsurprising that they have faced serious implementation problems and been unable to create growth or resolve the debt problems of the peripheral countries in EAPs. Their structure, though, reaffirmed the regulatory approach, assuming that crisis was down to bad behavior by their governments, that pain was a solution to an assumed moral hazard problem centered in public sector borrowers, and that reforms to produce growth would create a sustainable future fiscal profile.

When the newly elected Syriza-led government of Alex Tsipras challenged the Troika in 2015, it failed. Despite a referendum specifically rejecting the terms set by the Eurogroup of Eurozone finance ministers, negotiating on behalf of the Troika, the government caved and accepted a new and longer list of conditionalities for structural adjustment as the price of receiving ongoing ECB support and starting negotiations on a new EAP. The pain in Greece might demonstrate to voters in other creditor states that challenging the Eurozone power structure is futile. It also showed how some of the provisionality of the Troika is becoming entrenched. For example, the Eurogroup, despite being the key body negotiating on behalf of the ECB, Commission, and member states, was an informal group that refused to meet with the Greek Finance minister. Such informal groups are quite conventional in European governance, but it is something of a novelty for one to assume such power with so little formalization. Likewise, the ECB (below)'s restrictions on support for the Greek banking sector forced the economic crisis which caused Sryiza to back down, another remarkable action for a central bank with no such remit.

\section{The permanent reforms}

The Troika was a crisis measure with no clear basis in the treaties and a highly unorthodox relation to the legal and theoretical role of the Commission and ECB. Since 1992, Eurozone policymakers, unwilling to break up the monetary union or make sufficient internal transfers to cushion against economic shocks and imbalances, have instead focused on trying to make sure that states run tight enough budgets to withstand shocks. In practice, that has meant a long series of efforts to incorporate a bias towards tight fiscal policies and internal devaluation into fiscal policies across the EU.

There were a variety of theoretical ways to save the currency union, involving redistribution between people and governments but the only ones adopted are the ones that advance the European fiscal regulatory state (Hodson 2013). European elites, especially those of Northern European creditor countries, seem more willing to share rules than money (which makes sense if we assume that their voters do not trust the voters of other countries- if I do not trust you, regulating your behavior is more sensible than giving you money). Given

10 Perhaps the most obviously catastrophic of them all was the introduction of user fees for AIDS testing in some African structural adjustment programs (Stein 2008). 
that France had both Northern (large private bank exposure to peripheral government debt) and Southern (criticized for an overgrown state) characteristics, its position was ambiguous, which cemented Germany's position as the key actor.

The origins of the plan seem to lie with German Chancellor Angela Merkel's office, which wanted to support massive intervention to preserve the Eurozone but needed to promise German voters and possibly the German Constitutional Court that debtor countries were getting no free lunch and that no such interventions would happen in the future (e.g. Bastasin 2012; Hewitt 2013). There was little question that Germany would act to preserve the Euro. The Eurozone is a major market for German exports, and German banks were heavily exposed to European sovereign debt markets.

Stated theoretically, the idea is to harden the ineffective budget constraint on profligate nations. Lenders acted like the weaker Eurozone economies were ultimately guaranteed by the stronger Eurozone economies, creating what might be seen as a soft budget constraint (though as with much in this episode, the stated rationale is weak: it is not clear whether peripheral governments did ever assume they would be bailed out; the assumption that they thought they faced a soft budget constraint might be just empirically wrong). If there is a soft budget constraint, runs the argument, it will be exceeded, and lead to either bailouts with attendant moral hazard problems or crises (Rodden 2005 presents the argument well).

If repeated violations of the Stability and Growth Pact (SGP) meant a soft budget constraint then the EU certainly had one. The SGP was violated by every Eurozone state but Finland at some point after 2000 and was rewritten when enforcement proceedings threatened France and Germany, and that the accompanying Broad Economic Policy Guidelines (BEPG) were ignored the one time they actually led to a sanction on a member state (Ireland) (Hodson and Maher 2001; Hodson 2011). It is not hard to see why the old rules were not credible even before the EU commenced a series of enormous bailouts.

Member states would continue to have lots of reasons to violate the SGP, including principled disagreement with its theories or limitations on sovereignty, or desires to spend in order to maintain their own careers in government, or even the action of automatic stabilizers in bad economic times. What might look from one angle like credible commitment to responsibility by otherwise short-termist politicians could look from other angles like an effort to entrench certain right-wing approaches into law, or a manifesto for electoral ruin. As a result, runs the logic, a reformed SGP would have to be automatic and tough in order to effectively constrain the future policy decisions of democratic governments. The reformed EU fiscal regulatory architecture is an effort to make it automatic and tough enough to overcome all the reasons one might expect democratic politicians to break its rules.

\section{The "six-pack"}

The 2011 reform of the Stability and Growth Pact (SGP) was known as the "six-pack", consisting of four regulations and two directives. These six pieces of law were designed to formalize and strengthen the EU's fiscal surveillance regime -the regime that had failed to prevent the Eurozone countries from heading into a deep recession that threatened monetary union itself. Thanks to the crisis, member states that had failed to discipline themselves in previous years were now more willing (or more easily pushed) to bind themselves to a formal fiscal disciplinary regime.

The SGP has two arms: a preventative arm (Art. 121 TFEU), which focuses on monitoring member states' economies and economic policies, and a corrective arm (Art. 126 TFEU), which comes into play when states are non-compliant. Regulation 1175/2011 reformed the SGP's preventative arm, establishing an annual cycle of economic monitoring called the European Semester (elaborated below). It empowers the Commission and Council to formulate guidelines for economic and employment policy, monitor their implementation, and conduct surveillance to prevent and correct broadly defined 'macroeconomic imbalances'.

Council Regulation 1177/2011 reformed the SGP's corrective arm, which consists largely of the Excessive Deficit Procedure (EDP). It expands the EDP to focus not only on the Maastricht criterion for an excessive deficit, but also that for an excessive debt. The Commission decides if a member state has broken or is at risk of breaking either or both rules, with the Council deciding if an excessive deficit or debt then exists. Together, they make recommendations to the member state, which come with the risk of penalties -including changes in European Investment Bank lending policy, non-interest bearing deposits, and fines.

Regulation 1173/2011 enforces both arms of the SGP, specifying lodgements and fines for noncompliance with both the corrective and the preventative arms and penalties for falsifying statistics. The application of these penalties is made more automatic through the use of Reverse Qualified Majority Voting (RQMV), where recommendations are adopted unless a qualified majority vote passes the Council within 10 
days. The regulation also formalizes methods of working introduced in a more ad hoc way to combat the crisis by allowing the Commission to establish 'permanent dialogue' with states under the EDP.

Regulation 1176/2011 and Regulation 1174/2011 define the preventative and corrective arms of a new Macroeconomic Imbalance Procedure (MIP), a similar but parallel mechanism to the EDP that allows the Commission and Council conduct much broader fiscal surveillance that is not just limited to the Maastricht criteria. Imbalances are defined as 'any trend giving rise to macroeconomic developments which are adversely affecting, or have the potential adversely to affect, the proper functioning of the economy of a Member State or of the economic and monetary union, or of the Union as a whole' (Regulation 1176/2011, Art. 2(1)). Like the SGP, the Commission monitors and formulates recommendations under the preventative arm, creating a 'scoreboard' of economic indicators, while penalties for non-compliance are dealt with under the Excessive Imbalance Procedure, a parallel to the EDP that involves interest-bearing deposits, annual fines, and decisionmaking by RQMV.

Finally, Council Directive 2011/85/EU requires EU member states (except the UK) to adopt national fiscal rules that support compliance with the Maastricht reference values. These national rules must not only specify the target, but also outline the procedure for monitoring compliance and the consequences of failing to comply.

\section{The Treaty on Stability, Coordination and Governance}

The Treaty on Stability, Coordination and Governance (TSCG) was an attempt to build the six-pack's new emphasis on fiscal discipline into treaty law and tie it to a formal bailout mechanism -but it is not itself an EU law. Rather, it is a separate international treaty signed in 2012. Currently in force, the TSCG is binding on Eurozone states, while other states can choose to be bound in whole or in part once they adopt the Euro. The United Kingdom and the Czech Republic did not sign the treaty.

Because the TSCG is not an EU law, it runs in parallel with the six-pack, although there are many similarities between the two. The TSCG re-states the SGP's debt rule and definitions of excessive deviation and exceptional circumstances. States are required to move towards the same goals -medium-term objectives- they outline through the SGP.

But the TSCG goes further than the SGP in several key respects. It commits contracting states to a structural deficit no higher than 0.5 per cent of the GDP (or 1 per cent of the GDP for member states with debt below 60 per cent of the GDP). States must convert their commitments into national law of a 'binding force and permanent character, preferably constitutional', and create independent bodies to monitor their budgetary discipline. The TSCG, therefore, essentially constitutionalizes budget rules, taking the kind of "debt-brakes" (schuldenbremsen) seen in Germany and Switzerland to the EU level and diffusing them in member state constitutions.

Rather than the Council and Commission playing roles in enforcement, the Court of Justice of the European Union (CJEU) can require a state to implement the new rules, and impose fines for non-compliance. That is a far cry from the SGP's dependence on the Council doing the sanctioning, which obviously meant countries with voting power would never be willingly sanctioned. Eurozone members' fines will go to the ESM. Non-Eurozone member states under pressure, determined to stay close to the core of Europe, or with a taste for this kind of fiscal policy, can join the treaty. If they are fined, the funds go to the EU general budget.

The bailout mechanism is the European Financial Stability Mechanism (EFSM), which is a fund to be used to stabilize economies- in most cases, by buying debt. It is a change from the Maastricht framework because it envisions financial support to countries in trouble; the original Maastricht theory had no provision for bailouts as a condition of its passage. Receiving a bailout from the EFSM is conditional on adhering to the TSCG.

\section{The "Two-Pack"}

To consolidate the six-pack reforms, the TSCG, and the ad hoc arrangements created to deal with states facing the worst economic situations, two more regulations were passed in 2013, known as the 'two-pack'.

Regulation 473/2013 applies to Eurozone states not in distress -those not operating under Economic Adjustment Programmes. It adds a common timeline to the European Semester, strengthening the cycle of monitoring and policy recommendations carried out by the Commission. States must submit their draft budgetary plans to the Commission by October, which must contain 'relevant information on the general government expenditure by function, including on education, healthcare and employment, and, where possible, indications on the expected distributional impact of the main expenditure and revenue measures'. If a draft plan 
is non-compliant with the SGP, the Commission can ask the member state to revise it. The Commission assesses each plan and adopts an opinion on each by the end of November, along with a report on the budgetary situation within the Eurozone overall. Plans must be approved by national parliaments by the end of December.

Regulation 472/2013, the other half of the two-pack, applies to Eurozone states in distress -those receiving financial aid. It essentially formalizes and regularizes the Troika procedure for the future (necessary, given the fragile legal bases for the constitution and actions of the Troika in the 2010 and 2011 bailouts). These states can be made subject to 'enhanced surveillance' that goes beyond that required of other member states. Member states under enhanced surveillance must adopt corrective measures in consultation with the Commission and possibly other bodies including the ECB, ESAs, ESRB, or the IMF. In consulting with member states, the Commission can draw on the body of information it has gathered through the SGP and MIP, as well as information gained from interactions with the state (e.g. through the OMC), and analysis carried out by the ECB, ESAs and ESRB (stress tests, sensitivity analysis).

All of this consultation can be used to move member states in a particular direction. Through QMV, the Council can formally recommend that a state should adopt certain precautionary corrective measures or prepare a draft Economic Adjustment Programme. The Commission proposes the approval of the draft EAP, and the Council votes by QMV. Once approved, the Commission, in liaison with the ECB and IMF where necessary, is responsible for monitoring the EAP's implementation.

The reformed fiscal governance regime can seem like a logical next step in fiscal surveillance, the European integration, and the credible commitment that European policymakers say markets demand of countries with the debt and poor demographic prospects of the EU members. It implements what are called debt-brakes in the original German (balanced budget rules)- something a number of countries had been doing anyway, whether out of general worry (Germany) or when under market pressure during the crisis (Spain). As for surveillance, that principle has long been established- since Bretton Woods at least - and the specific power of an EU institution to discipline states for bad budget problems was established in the SGP.

This version, unlike the SGP or recommendations from economists, promises to effectively hold governments to a new rule that is enforced by a mixture of domestic courts, EU agencies and the CJEU itself. Budgets now must be constitutionally regulated by third party enforcers- if not the new domestic agencies or member state courts, then the CJEU itself. It might not be a good idea for a democracy to decide to run a structural deficit of more than $0.5 \%$ of GDP; in the EU it is illegal. The magnitude of this change is stunning: in 2010, when many countries were dealing with the effects of a revenue collapse and financial crisis, they all ran far higher deficits: the United States (8\%), the UK (7.9\%), Spain (7.5\%), the Netherlands $(5.7 \%)$, Ireland (8.6\%) and Greece $(7.4 \%)$. Even relatively prosperous Germany $(3.1 \%)$ and parsimonious Italy $(3.6 \%)$ were delinquent by this standard (Kumhof and Rancière 2010). In general, we know a great deal about the effects of balanced budget rules from the American state government (Greer and Jacobson 2010). They are procyclical, discourage social policy innovation and long-term planning, are generally regressive in effect (social welfare and education get cut) and produce budgetary trickery.

With the Fiscal Compact, a contestable if not falsified economic theory (Blyth 2013) is now constitutional law in Europe. Governments are to be suitably constrained, with negative effects on their citizens' ability to participate in the decisions of a meaningful political power.

\section{The European Semester}

The European Semester's name might suggest a one-off academic exercise, but it is a core part of the EU's new fiscal governance regime and arguably an ambitious, coherent, and agenda-driven example of "new governance" that goes beyond older and less effective models such as the BEPG and OMC. It draws on extensive Commission surveillance, as well as member state self-review, and the intent is to go far deeper into member state decisions. In the European Semester, the Commission Directorate-General and Council formation for economic and financial affairs manage a process that debates every country's budget in detail for not just macroeconomic compliance, surveillance compliance, and budgetary compliance, but also for policy content that reinforces the desired outcomes (ensuring that heterodox routes to the orthodox outcomes are not tried). The centrepiece of the European Semester is the Country Specific Recommendations (CSRs), in which the Commission, after receiving data and plans from governments, makes suggestions about what the governments should do.

The Semester has three separate legal bases, and each CSR is clear about which recommendations have which legal bases. One is the SGP, and is punitive. One is the MIP, and is also punitive. The third is Europe 2020, a strategy adopted by the Barroso Commission to replace the Lisbon Agenda as a theme for EU action. It highlighted "differentiated, growth-friendly fiscal consolidation, restoring normal lending to the economy, 
promoting growth and competitiveness, tackling unemployment and the social consequences of the crisis, and modernising public administration" as the EU's goals (European Commission 2011). Predictably, the new Juncker Commission has no investment in their predecessors' project, but there is no clear sense as of late summer 2015 of what might replace it. The 2015 CSRs still draw on it for a variety of their suggestion. Unlike the MIP and SGP bases, there is no base for coercive action should a member state ignore a CSR based on Europe 2020 or any strategy that replaces it.

Each country submits statistics (newly structured and better collected, if the rest of the six-pack is taken seriously) and its plans to improve its performance in these areas. The "semester" comes about because it runs on an annual cycle, starting in 2012, of two six-months periods during which states must make and report adjustments that will allow them to hit their targets. The Commission is the principal judge of their compliance.

While it remains to be seen if the agenda expands and contracts, in the manner of the Open Method of Coordination (OMC), the initial goals are tightly bound to the founding Regulation and the context of the sixpack. In an echo of the OMC, there is an apparatus for local and regional governments to participate in monitoring the Semester's progress. Civil society is encouraged to participate in the member states' formulation of their national action plans, and is otherwise supposed to be represented by the participation of the Economic and Social Committee in the Semester evaluations. The European Parliament has an opportunity to comment. The situation within the Commission is still evolving, but it seems that through strenuous internal politics DGs other than ECFIN are finding a role in the Semester and CSRs (for example, DG EMPL is invited to develop social and labor policy advice, and it invites health policy ideas from DG SANCO- though EMPL decides what it accepts from SANCO and ECFIN decides what it accepts from EMPL in its recommendations to the ECOFIN council).

This process largely excludes civil society, social policy ministries, and legislative accountability in most countries, but the advisory mechanisms that produce opinions and soft law are open to bureaucratic infiltration. More socially inclined politicians and bureaucrats in Brussels are especially using these fora to argue against reforms they find objectionable and ways to include their priorities in "promoting growth and competitiveness" (through human capital strategies, probably), and "tackling unemployment and the social consequences of the crisis" (Vanhercke 2013). These consultative mechanisms are the main vehicle by which some ideas from the more left-leaning "social" sector of the EU can enter the Commission's thinking in what Jonathan Zeitlin calls the "socialization" of the European Semester (Zeitlin 2015). This is not the first time, after all, that the EU leaders have agreed on an essentially right-wing competitiveness agenda that slowly incorporated more and more social and environmental policies; that is the experience of the Lisbon agenda, for example. Even if the Lisbon agenda did little to advance social or environmental policy, the incorporation of social and environmental goals diffused its political force.

Three things stand out about the European Semester. One is the breadth and depth of its claims about member state policymaking. Country-Specific Recommendations (CSRs) ${ }^{11}$ can be very specific indeed; Austria, for example, is told that its health system requires clearer lines of authority, greater use of primary care and less hospitalization, and a better medium-term financing mechanism (Austria is hardly a country in obvious crisis, but the CSRs did almost perfectly mirror the reform plans of the incumbent Austrian government). In 2015, the French were told, with the SGP as a treaty base, to reform (remove) the numerous clausus limiting admission to education for health professions. In theory, at least, France, which is in an Excessive Deficit Procedure could be fined for endangering the Eurozone with its rash fiscal policies if it were to ignore the recommendation to review admissions policies of medical schools.

Even if it is unlikely that France will be fined for its approach to medical education, this is a quite astonishing change in the governance of the EU. The EU had previously limited authority to address member state policies, let alone make clear recommendations in areas such as health, where the Lisbon Treaty reaffirmed member state responsibility for the organization and finance of health care services. Now it does, so long as the objective is fiscal rigor; the Semester procedure includes attention to both expensive welfare services such as pensions and health, and calls for reform in areas such as labour market policy- in other words, most of the areas of social policy that member states have been reluctant to turn over to the EU responsibility. It is also a clearly political process, with the Commission making sectoral recommendations based not on its own risk assessment but rather focusing on areas where it judges its impact greatest (Greer, Jarman and Baeten 2015). That includes not making tough recommendations to non-Eurozone or notably Eurosceptic governments; the UK notably escapes CSRs that are otherwise indicated.

The second aspect is the hardening of the soft law. Where do the detailed recommendations in the EAPs or CSRs come from? The answer is the large fund of data and reform proposals assembled by oftenderided EU soft law projects such as the OMC, in particular the Economic Policy Committee. Even if the

11 For which, see http://ec.europa.eu/europe2020/making-it-happen/country-specific-recommendations/index_en.htm 
OMC's effects in the expected areas (learning, peer review, etc) were generally limited and contingent on local politics (e.g. De la Porte 2010; Greer 2011), they created a large fund of detailed and superficially consensual policy reform ideas. Member states rarely paid much attention to the processes producing their recommendations and reform plans, but those reform ideas and comparative data sets are now being used by DG ECFIN and the ECOFIN council, as well as the Troika, to propose detailed interventions into member state policies. Soft law paved the way for some very much harder law. How much harder remains to be seen.

The third is the extent to which the Semester process is structurally biased towards austerity- its purpose is to promote fiscal sustainability and "competitiveness" and its ultimate rationale fiscal policy coordination- but might be losing some of its focus. Within the Commission, for example, it is run by DG ECFIN, and other DGs with more social interests are in an essentially subservient advisory role; in the Council, it is ECOFIN, the finance ministers, who run the process ${ }^{12}$. Since the arrival of the Juncker Commission ("a German commission" as a Commission official told one of us in May 2015), DG ECFIN has lost some of its role because its commissioner is a French Socialist, and the Secretariat General, responsible to Juncker, has taken a more commanding role.

The process systematically excludes legislatures and civil society, empowering the EU vis-à-vis states, and states vis-à-vis social interests. A study of the increasingly numerous health policy CSRs concludes that they "are framed as a means to the objective of ensuring sustainability of public finances and not as part of the pillar on combating poverty and social exclusion" and finds "a shift away form concentrating only on the financing of health systems as a lever for policy reform but also shows how health care organization and delivery is also recently being targeted as an area for policy reform;" it finds an association between public debt and CSRs, "indicating that the performance of the health system is a secondary consideration to the overall country financial situation" (Azzopardi-Muscat et al 2015: 6), while other studies suggest that the CSRs are indeed changing member state policies in detailed areas (Stamati and Baeten 2015, Greer, Jarman and Baeten 2015). The "socialization" of the Semester seems to be proceeding slowly.

\section{The ECB as microeconomic and macroeconomic policymaker.}

The EU, then, has multiple complex and overlapping mechanisms, not to mention a long history of policy experiments, all intended to enforce the Stability and Growth Pact. Compliance with the SGP is supposed to compensate for the otherwise serious problems of a currency union with serious deflationary tendencies and a constant risk of debt crisis: if every member state pursues the combination of strict fiscal policy and liberalized economics, runs the theory, then the Eurozone will be safe from crisis. On one hand, the argument has little obvious validity. Spain and Ireland were model SGP-compliant states when Germany was breaking the rules (justified by the costs of its own labour market liberalization, Hartz IV) and were undercut by the combination of speculative capital outflows, private banking extravagance, and a rigid currency union. On the other hand, it is not clear that the multiple, and multiplying SGP enforcement mechanisms developed by the EU since 2010 had any positive effect on the survival of the Eurozone. Rather, the ECB seems to be what saved the Euro by convincing bond traders that they could not win by betting on a Eurozone member state exiting the currency union.

Dyson (2001) realized immediately that the political order of the Eurozone was "ECB-centric", with a largely unaccountable central bank prominent in an institutional landscape otherwise prone to gridlock, but it took a decade to show just how right he was. It is unsurprising that a gridlocked political system such as the EU, in which the only area of intergovernmental agreement is on fiscal constraint, does not produce activist economic policies among governments- and that the unelected central bank is therefore freest to make new policy.

The ECB was designed to be unaffected by democracy, as part of both a recent worldwide move towards anti-inflation independent central banks and a concession to Germany, where the hard-money Bundesbank, in the context of the German political economy, contributed greatly to growth and stability (Dyson and Featherstone 1999; Hall 1994; Hall and Franzese 1998). Dyson (2014) notes the remarkable success of the Bundesbank in spreading its eccentric theories about German economic history, economic policy, and German preferences despite the inaccuracies of its ideas. The theory, broadly endorsed by the economics profession, is that the way to make a group of people such as bankers more predictable is to make them less accountable. The micro-foundations of this proposition are unclear)(Adolph 2013). This means that while the continent was binding itself to the SGP goals, the ECB was autonomous and able to pursue much more radical and supportive

12 Council formations cannot directly comment on each other's work, so when the health ministers' Council wanted to register concerns about the austerity focus of the Semester's health policies, it had to do it through an extended commentary on a working group's report. See "Council conclusions on the reflection process on modern, responsive and sustainable health systems"

http://www.consilium.europa.eu/uedocs/cms_data/docs/pressdata/en/lsa/140004.pdf 
policies (the combination of a fiscally austere political system with an activist central bank was hardly unique to Europe, as the UK and USA both showed).

The European Central Bank might have been set up- in treaty and in culture- to have very limited interventionist powers, but, as many central banks have done, it took dramatic action in a crisis. There are two clear ways it has done so. One is by the classic central banker's actions, supplemented by newer forms of quantitative easing: Mario Draghi famously promised to do "whatever it takes" to preserve the Euro, ${ }^{13}$ and bond yields in peripheral Europe immediately began to stabilize (Hodson 2013). After he outlined the "Outright Monetary Transactions" (OMT) program on 6 September 2012, interest rates on government debt from weaker Eurozone economies dropped further and have remained stable or shifted downward since. OMT would involve buying government debt subject to government compliance with conditionalities set by the rest of the EU. It is also not clear that the OMT would be legal under the EU (or German) law. Fortunately, markets were reluctant to bet against a fully engaged central bank, and speculative attacks ceased (allowing the Cypriot operation, involving a Troika intervention and currency controls, to take place without causing another crisis). Second, the Eurozone economy has been stagnant, leading to announcements in September 2014, that the ECB would consider unorthodox quantitative easing, followed by a specific program announced in January 2015.

The ECB, as a guardian of the Eurozone monetary system and an actor free to intervene, also carved out a surprising role for itself in the Troika, one reinforced by the promise of selectivity in the OMT program (the conditionality for participation). The ECB is completely opaque about its operations, including its role in the Troika. There were essentially no public statements by the ECB explaining the conditions under which it would engage in any kind of unusual activity in support of a country, but its new self-appointed role in public administration, labour law reform, land use planning, and other aspects of the EAPs suggested that it would use its monetary tools to treat countries differently based on its perception of their public policies, its help to treasuries and private banks dependent on compliance with EU policy views.

Among other things, this means that he ECB can reasonably be said to have changed at least two Eurozone governments' composition. First, it seems that the ECB forced out Silvio Berlusconi. A central bank manipulating market expectations to change a Prime Minster is possibly the only thing worse for Italian democracy than Berlusconi himself (Jones 2012; Hopkin 2012). ${ }^{14}$ In 2015, then, the ECB chose not to expand support for Greek banks during the bank run caused by failed negotiations between the Greek government, Troika, and Eurogroup. This was the precipitating factor in the Greek government's capitulation and the resignation of its highly visible finance minister. There might be a theory under which this action has democratic legitimacy, but it would be an indirect one.

\section{Conclusion}

There are now multiple redundant, overlapping mechanisms for imposing austerity on member states. They include the kind of receivership currently being experienced in the EAP countries as well as variety of formal structures built into the Fiscal Compact, six pack, and two pack, and older mechanisms such as the EU strategies and the OMC. Why does the EU need so many Rube Goldberg policy regimes, all aimed at accomplishing the same, conceptually simple goal low deficits and debts relative to the GDP? These redundant mechanisms only make sense in the context of European policymakers who, correctly, fear, that democratically accountable politicians will not abide by those austere and essentially arbitrary goals, that debt markets will be aware of that and that electorates in creditor countries will want a pound of flesh from their debtors. In other words, they are trying to re-create the discipline of the gold standard through a mixture of hard and soft law.

Put together, the result is a big step forward for European integration, but a big step in the same direction it was heading before the crisis: towards a fiscal regulatory state, one built on regulations that are hard to enforce, intrude deeply into domestic public and social policy, and create losses without any compensation. The area of possible compromise between European leaders- on a fiscal regulatory state- did not change with the crisis, even if there was little or no evidence that the resulting policies worked on their own terms or supported broader objectives such as growth or equity. But even if the whole apparatus of fiscal governance and conditional lending was a smokescreen to permit the bailouts and central bank activism that ended the crisis, it remains in place nonetheless. Even if it looks like it was set up to fail, it is entrenched in law, treaties, and member state constitutions, and in theory subjects member states to a broad, deep, and automatic mechanism that shapes their fiscal and therefore public policies.

13 Paul Carrel and Noah Barkin and Annika Breidthardt, Reuters. Tue Sep 25, 2012 Special Report: Inside Mario Draghi's euro rescue plan http://www.reuters.com/article/2012/09/25/us-ecb-draghi-plan-idUSBRE88O09A20120925

14 See also: From Ceremonial Figure to Italy's Quiet Power Broker. Rachel Donadio. New York Times, 2 December 2011.

https://www.nytimes.com/2011/12/03/world/europe/president-giorgio-napolitano-italys-quiet-power-broker.html?pagewanted=all\&_r=0 
The long-term fate of the structure remains to be seen. On paper it is a substantial increase in power and responsibility for the EU vis a vis member states, and member state governments vis a vis actors such as parliaments and social partners, but there are good reasons to expect that it will fail on its own terms. Right-wing governments that are intellectually sympathetic to the agenda, such as Spain's, have had difficulty hitting their targets and have had to engage in the coalition-building necessary to avoid sanctions. Less right-wing governments, such as that of France, are openly threatening to break the fiscal rules. The responses to their challenges tends to blur the supposedly clear and automatic rules and decisions of the EU institutions; one possible outcome over time is that the whole mechanism remains, invasive and complex, but becomes as toothless as the BEPG or OMC (Greer 2014b).

What would happen if the EU were not dominated by parties of the right? What if policymakers began to conclude, after a long time, that their competitive liberal orientation is unjustified and inflation tolerable (McNamara 1998)? Or what if governments of the right could not hit the SGP targets in a bad economy without destroying automatic stabilizers and creating a social emergency that could have electoral consequences? The best evidence is that fiscal performance in Europe is affected by economic conditions, almost to the exclusion of other factors (LeMay-Boucher and Rommerskirchen 2014). That suggests that even a small downturn in the European economic performance- such as what appears to be happening in 2015- will push member states away from compliance.

And finally, there is not much evidence that the program, were it to be enforced, would produce growth. An enormous amount of research shows that there is no simple relationship between fiscal rigor and growth, including comparative political economy that points out the ways in which different economies respond to monetary and fiscal policies (the central preoccupation of the study of political economy; for an example applied to the Euro crisis, see Hall 2012). The work of Alesina, Reinhart, and Rogoff on "expansionary austerity" (Alesina 2010; Alesina and Ardagna 2010; Rogoff and Reinhart 2010; Reinhart, Reinhart and Rogoff 2012) that provided the intellectual colouring for many crisis policies has been falsified (Herndon, Ash and Pollin 2013; Guajardo, Leigh and Pescatori 2011). At most, crisis-hit countries seem to be reverting to the mean, with some positive but minimal growth. European politicians frequently seem to talk as if growth is a binary variable, with growth present or absent. In reality, it is possible to have very low growth, and that is the situation of much of the Eurozone. If the ECB were not defending the Eurozone, and the Eurozone states it deems worthy, it is hard to say that they would be escaping debt or economic crisis.

In short, Europe's fiscal regulatory state has a very poor record on any terms but European leaders have increased their bets on it. Without any distributive or redistributive policies, the fiscal crisis response mechanisms of the EU and its member states are very weak. That means that avoiding crisis by avoiding fiscal problems is the only clear EU strategy, and that means betting heavily on a mechanism whose deficiencies are clear, whether we regard their weaknesses in terms of the difficulty of fiscal self-binding by short-termist politicians, or the highly political, distributive nature of the decisions it is taking, or the weakness of the economic theory underlying the policies. The most successful part of the system- as in, the part with any apparent success on its own terms as a discipline on member states- is probably the Semester, where it can empower governments who wish to pursue liberalizing policies against domestic opposition.

As Karl Polanyi (1944) explained in the context of the gold standard, a rigid monetary policy that pushes all the burden of adjustment onto society, without countervailing regulation and welfare states, will be unstable and deflationary at best, and create far greater crisis at worst. Europe's regulatory fiscal state has all the drawbacks of the gold standard but without its simplicity and brutal enforcement mechanisms. Policy since the crisis has been an effort to create that simplicity and power through surveillance and punishment, but for all its redundancy and intrusiveness it probably still falls short. Europe's fiscal regulatory state can do much to constrain public policy and advance a certain kind of European integration, but it is still unlikely that it will be able to force on democratic member states the degree of suffering the Euro seemingly requires. That might be a blessing.

The effort to recreate the economics of the gold standard through regulation sets up a potentially dangerous situation for the EU. The EU has taken a big step forward with the expansion of its fiscal regulatory state and it is already influencing policy. But its success on its own terms as a disciplinary mechanism or in light of broader objectives remains doubtful. The consequences are easy to view in the combination of unpalatable dilemmas that face voters and governments in Eurozone states, in the inevitable fudging of supposedly clear rules, and in the policies enacted in a continent where, as ECB President Draghi says, the "European social model is already gone."15 Whether such a structure can persist remains to be seen.

15 Q\&A: ECB President Mario Draghi. The Wall Street Journal. Eurocrisis blog. 23 February 2012. http://blogs.wsj.com/eurocrisis/2012/02/23/qa-ecbpresident-mario-draghi/. Draghi was arguing that high youth unemployment shows that the social model in question is gone. 


\section{Bibliography}

Adolph, Christopher. 2013. Bankers, Bureaucrats, and Central Bank Politics: The Myth of Neutrality. Cambridge: Cambridge University Press.

Alesina, Alberto. 2010. "Fiscal Adjustments: Lessons From Recent History." Presentation to ECOFIN Meeting, Madrid, April 15.

Alesina, Alberto and Silvia Ardagna. 2010. "Large changes in fiscal policy: taxes versus spending". 35-68 in D. Brown, ed. Tax Policy and the Economy, Volume 24. The University of Chicago Press.

Azzopardi-Muscat, Natasha, Timo Clemens, Deborah Stoner, and Helmut Brand. 2015. "EU Country Specific Recommendations for health systems in the European Semester Process: Trends, discourse and predictors". Health Policy advance online publication. doi:10.1016/j.healthpol.2015.01.007

Bastasin, Carlo. 2012. Saving Europe: How National Politics Nearly Destroyed the Euro. Brookings Institution Press.

Blyth, Mark. 2013. Austerity: the History of a Dangerous Idea. Oxford: Oxford University Press.

Boyer, Robert. 2013. "Origins and Ways Out of the Euro Crisis: Supranational Institution Building in the Era of Global Finance." Contributions to Political Economy 32:97-126.

Dyson, Kenneth. 2001. The Politics of the Euro-Zone: Stability or Breakdown? Oxford: Oxford University Press.

Dyson, Kenneth. 2014. States, Debt, and Power: 'Saints' and 'Sinners' in European History and Integration. Oxford: Oxford University Press.

Dyson, Kenneth, and Kevin Featherstone. 1999. The Road to Maastricht: Negotiating Economic and Monetary Union. Oxford: Oxford University Press.

Easterly, W. 2005. "What Did Structural Adjustment Adjust?: The Association of Policies and Growth with Repeated IMF and World Bank Adjustment Loans." Journal of Development Economics 76:1-22.

Greer, Scott L. 2011. "The Weakness of Strong Policies and the Strength of Weak Policies: Law, Experimentalist Governance, and Supporting Coalitions in European Union Health Care Policy." Regulation \& Governance 5:187-203.

Greer, Scott L. 2014a. "Structural Adjustment Comes to Europe: Lessons for the Eurozone From the Conditionality Debates." Global Social Policy 14(1)51-71

Greer, Scott L. 2014b. “The three faces of European Union health policy: Policy, markets, and austerity”. Policy and Society 33(1):13-24.

Greer, Scott L., Nick Fahy, Heather Elliott, Matthias Wismar, Holly Jarman and Willy Palm. 2014. Everything you always wanted to know about European Union bealth policy but were afraid to ask. Brussels: European Observatory on Health Systems and Policies.

Greer, Scott L., Holly Jarman, and Rita Baeten. 2015. The new political economy of health in the European Union. International Journal of Health Services. In press.

Guajardo, Jaime, Daniel Leigh, and Andrea Pescatori. 2011. Expansionary Austerity: New International Evidence. International Monetary Fund.

Hall, Peter A. 1994. "Central bank independence and coordinated wage bargaining: Their interaction in Germany and Europe" German Politics and Society 31(1)1-23.

Hall, Peter A. 2012. "The Economics and Politics of the Euro Crisis." German Politics 21:355-371.

Hall, Peter A. and Franzese, Robert J. 1998. "Mixed Signals: Central Bank Independence, Coordinated Wage Bargaining, and European Monetary Union" International Organization 52(3)505-535.

Herndon, Thomas, Michael Ash, and Robert Pollin. 2013. Does High Public Debt Consistently Stifle Economic Growth? A Critique of Reinhart and Rogoff. Amherst: Political Economy Research Institute, University of Massachusetts Amherst

http://www.peri.umass.edu/236/hash/31e2ff374b6377b2ddec04deaa6388b1/publication/566/. 
Hewitt, Gavin. 2013. The Lost Continent: Europe's Darkest Hour Since World War Two. London: Hodder \& Stoughton.

Hodson, Dermot. 2013. "The Eurozone in 2012:'Whatever It Takes to Preserve the Euro'?" JCMS: Journal of Common Market Studies 51:183-200.

------. 2011. Governing the Euro Area in Good Times and Bad. Oxford University Press.

-----. 2013. "The Little Engine That Wouldn't: Supranational Entrepreneurship and the Barroso Commission." Journal of European Integration 35:301-314.

Hodson, Dermot, and Imelda Maher. 2001. "The Open Method As a New Mode of Governance: The Case of Soft Economic Policy Co-ordination." JCMS: Journal of Common Market Studies 39:719-746.

Hopkin, Jonathan. 2012. "A Slow Fuse: Italy and the EU Debt Crisis." The International Spectator 47:35-48.

Huber, E. and Stephens, J. D. 2012. Democracy and the Left: Social Policy and Inequality in Latin America. Chicago: University of Chicago Press.

Jones, Erik. 2012. "Italy's Sovereign Debt Crisis." Survival 54:83-110.

Kelemen, R. Eurolegalism: The transformation of law and regulation in the European Union. Cambridge: Harvard University Press.

Kelemen, R, and Terence Teo. 2012. "Law and the Eurozone Crisis." APSA 2012 Annual Meeting Paper.

Kumhof, M, and R Rancière. 2010. "Inequality, Leverage and Crises." IMF Working Papers 1-37.

De la Porte, C. 2010. "State of the Art. Overview of Concepts, Indicators and Methodologies Used for Analyzing the Social OMC." Working Papers on the Reconciliation of Work and Welfare in Europe.

Lefkofridi, Zoe, and Philippe P. C. Schmitter. 2014. "Transcending or Descending? European Integration in Times of Crisis." European Political Science Review 1-20.

LeMay-Boucher, Philippe, and Charlotte Rommerskirchen. 2014. "An Empirical Investigation Into the Europeanization of Fiscal Policy." Comparative European Politics.

Majone, Giandomenico. 1994. "The Rise of the Regulatory State in Europe." West European Politics 17:77-102.

McNamara, Kathleen R. 1998. The Currency of Ideas: Monetary Politics in the European Union. Ithaca: Cornell University Press.

Pasimeni, Paolo. 2014. “An Optimum Currency Crisis” European Journal of Comparative Economics 11(2)173-204.

Peabody, J W. 1996. "Economic Reform and Health Sector Policy: Lessons From Structural Adjustment Programs." Soc Sci Med 43:823-35.

Polanyi, Karl. 1944. The Great Transformation: The Political and Economic Origins of our Time. Boston: Beacon.

Reinhart, Carmen M, Vincent V. R. Reinhart, and Kenneth K. S. Rogoff. 2012. "Public Debt Overhangs: Advanced-economy Episodes Since 1800." The Journal of Economic Perspectives 26:69-86.

Rodden, Jonathan A. 2005. Hamilton's Paradox: The Promise and Peril of Fiscal Federalism. Cambridge: Cambridge University Press.

Rodrik, Dani. 2006. "Goodbye Washington Consensus, Hello Washington Confusion? A Review of the World Bank's Economic Growth in the 1990s: Learning From a Decade of Reform." Journal of Economic Literature 44:973-987.

Rogoff, Kenneth, and Carmen Reinhart. 2010. "Growth in a Time of Debt." American Economic Review 100:573-8.

Schelkle, Waltraud. 2009. "The Contentious Creation of the Regulatory State in Fiscal Surveillance." West European Politics 32:829-846.

Stamati, Furio and Rita Baeten. 2014. Healthcare reforms and the crisis. Brussels: ETUI/OSE

Stein, Howard. 2008. Beyond the World Bank Agenda: An Institutional Approach to Development. Chicago: University of Chicago Press.

Vanhercke, Bart. 2013. "Under the Radar? EU Social Policy in Times of Austerity." Pp. 91-120 in Social Developments in the European Union 2012, edited by Bart Vanhercke and David Natali. Brussels: ETUI/ OSE.

Vreeland, J R. 2007. The International Monetary Fund: Politics of Conditional Lending. Routledge Abingdon. 
Zeitlin, J. and B. Vanhercke. Socializing the European Semester? Economic Governance and Social Policy Coordination in Europe 2020. Report prepared for the Swedish Institute of European Studies. Brussels: European Social Observatory (OSE). 